The Journal of Animal \& Plant Sciences, 30(4): 2020, Page: 860-868

ISSN: 1018-7081

\title{
A CASE STUDY OF BEAR REINTRODUCTION IN PAKISTAN: ART AND POLITICS IN CONSERVATION
}

\author{
Fakhar-i-Abbas ${ }^{1}$, A. Mian $^{1}$, N. A. Raja ${ }^{2}$, S. Shah ${ }^{3}$ and Jan-Schmidt-Burbach ${ }^{4}$ \\ ${ }^{1}$ Centre for Bioresource Research, 34-Bazaar Road, G-6/4, Islamabad, Pakistan \\ ${ }^{2}$ Directorate of Biodiversity Ministry of Climate Change Islamabad Pakistan \\ ${ }^{3}$ Directorate of Wildlife Ministry of Forest Government of KPK Pakistan \\ ${ }^{4}$ Leipzig University, Leipzig State of Saxony, Germany \\ Corresponding author's email: fakharabbas@hotmail.com
}

\begin{abstract}
Bears are Pakistan's largest terrestrial animals. Conservation status of brown bears is least concerned and black bear is vulnerable in the world, and critically endangered (brown) (Ahmed et.al. 2013: Sheikh and Molur 2004) and threatened in Pakistan. It is reported that roughly $92 \%$ of past black bear habitat is now empty or without them. Similarly 30\% previously known distribution has now lost its population in Pakistan. Considering the problems this species is facing, a reintroduction plan was organized in which the confiscated bear cubs from poachers were raised in a specialized and least human contact enclosure. Considering regional habitat difficulties, the sites were properly studied and discussed. Due to an appropriate monitoring system, five rehabilitated bears were readied for release in those habitats in the last three years. Monitoring of the released individuals confirmed their survival and success in their adaptation. The first year release was not discussed publicly so complaints or any negative impact was never discussed. Second year release because of the involvement of the country's prime minister went public. The media itself reported positively. The conservationists unanimously opposed the release for their own reasons. The second released bears were several times reported as poached, road killed, hunted with their parts sold in the market and five times destruction caused by them was reported at an area of our 50,000 square kilometers. This report is being presented with a hope that politics in conservation efforts could be reduced. Silent conservation efforts are more successful for nature but do not aware masses for future motivation and real impact, it is done with loud and clear message the fellow conservationists turn into competitions and they try to fail the efforts.
\end{abstract}

Key words: Asian black bear. Ursus thibetanus. Reintroduction. Rehabilitation. Human wildlife conflict. Bear conservation. Bears population management. Population management. Bears of Pakistan.

https://doi.org/10.36899/JAPS.2020.4.0101

Published online April 25, 2020

\section{INTRODUCTION}

Two species and four sub-species of bears have been reported from Pakistan. Baluchistan black bear was though once reported extinct in the wild yet some recent indirect sightings have been reported from isolated localities. Himalayan black bear occupancy contracted from $11,807 \mathrm{~km}^{2}$ in $1950 \mathrm{~s}$ to $7,925 \mathrm{~km}^{2}$ in 2014 (14.6\% decline), and now some 600 individuals are possibly surviving as six isolated populations (some with $<10$ heads) at lower altitudes of Khyber Pakhtunkhwa (KP), Gilgit-Baltistan (GB), and Azad Jammu and Kashmir (AJK) having forested vegetation, thicker human habitation and associated agriculture. Himalayan brown bear occupancy declined by $13.3 \%$ between 1950s $\left(17,031 \mathrm{~km}^{2}\right)$ and $2104\left(12,147 \mathrm{~km}^{2}\right)$ and now some 250 individuals are believed surviving as six isolated populations at highland pastures and upper limits of coniferous forests of KP, GB and AJK; having thinner human habitation/agriculture but high number of transhumant maintained livestock. Some unconfirmed reports suggest presence of Syrian brown bear in northwestern parts of KP and GB. Bears raiding agricultural crops, livestock predation and human attack have been reported (Abbas et.al 2015). Population isolation and inbreeding, cub poaching, retaliatory killing, trade for bear parts and habitat loss are the major conservation problems. Some $70-80 \%$ decline has been indicated during last 50 years in global bear population (IUCN 2018). Highlighting importance of conservation efforts for bears in the wild. Bears, being Pakistan's the largest terrestrial wild mammal of Pakistan, are important species requiring active conservation measures.

Bears in Pakistan are used in acrobatics, street dancing and fighting with dogs, in both urban and rural areas. For the purpose cubs are poached (usually a few months old, poached after killing mother) and are trained for acrobatics. To curb this menace a high level of vigilance is exercised to stop bear cubs entry into the system. Sometime the poached cubs are recovered/ rescued through law enforcing agencies. Under current 
practices four options are exercised for the rescued cubs under different situations:

1. Release them back in wild immediately to fend them.

2. Place them in zoo permanently.

3. Place them in rehabilitation centers permanently.

4. Euthanize them.

Chances of survival of bear cubs less than 7 months old when released into wild are very low as they cannot defend themselves in the absence of mother's protection (Erickson 1959, Palomero et.al. 1997), mainly because bears are shy and solitary for most of the year except for their family (Alt and Beecham 1984, Beecham and Watkin 2005, Binks 2008). All other options suggest soft (permanent maintenance in rehabilitation center), tortured (under zoo conditions) or harsh (euthanizing) killing of cubs, which can never be regarded as positive. All such options support extraction of bear's wild population and probably no special advantage of confiscating the cubs, except some level of deterrence for the poachers and associated business chain.

Some of the rescued/ confiscated orphan bear cubs reach the Federal Rescue Centre (Balkasar, Punjab, Pakistan) where state of the art facilities are available for rehabilitation of bears. A better option could be the reintroduction of the confiscated bear cubs back in nature after their rehabilitation at an age and prepared to defend them themselves when they can support genetic diversity of natural bear populations or repopulate the recently vacated habitat areas of the species. The efforts to reintroduce blackbuck (Antilope cervicapra), chinkara (Gazella Bennetti) and cheer pheasant (Catereus Wallichii) in Pakistan tried during 1990's have unfortunately been unsuccessful, while reintroduction of carnivores, including bears, was never tried.

Reintroduction of bears, with an omnivorous habit, involves risk of human safety, and livestock and crop damages, thereby having negative public attitude (Beck et.al 2004). For a protected area/national park these risks are not serious as per its mandate (Gulez 1992). Bears have large home range and northern areas of Pakistan have low bear and low human population densities with plenty of bear habitats available, all supporting species reintroduction. In these areas the reported frequency of bear attacks on humans/livestock and raiding of crops has decreased (Meriggi and Loveri 1996, Khorozyan et.al. 2015). Though no consolidated study is available yet cats and canids are believed to cause more damage than ursides (Dar, 2009, Shehzada et.al. 2015, Ali et.al. 2016, Ahmed et.al. 2013). Mass killing of livestock (almost 100) is associated with wolves (Beck et.al 2004). The important actors of reintroduction program are not directly involved populace, but the critics, including other conservation organization, government relevant departments, or pessimistic individuals (Victor 2006).

Present report presents case study of successful reintroduction of bear cubs into the recently vacated habitats; brown in a national park and black in an unprotected area. The bear cubs used were confiscated by relevant wildlife departments and rehabilitated at Federal Rehabilitation Center. We adopted hard release method, the soft release being expensive and is useful only where reintroduction is designed for some defined area.

Cub Rehabilitation: Rescue/rehabilitation center (50 Acre) is located in a hill slope facing the River Dhrabi at an altitude of $620 \mathrm{~m}$ asl., having wild environment. The construction material and enclosure sizes are designed to keep animals acquainted with wild environment (Beecham and Watkin 2005) and accredited by the Government of Pakistan. The number and size of enclosures give flexibility to house bears of different types and conditions, as per recommendations of NWRA (Miller 2000). Infants are kept separately, with appropriate feed and controlled conditions, housed in carrying kennel type boxes covered with cotton towels. At the age of 8-12 weeks infants are moved to a larger space, allowing interaction with other cubs, with a shelter from rain and extreme temperature. After the age of 12 weeks, they are given still larger space with smaller shaded area (Vickery and Mason, 2003; Criswell and Galbreath, 2005). Heavy gauge woven wore or net wire, bricks and concrete with a lot of vegetation along with wood $\operatorname{logs}$ are the main construction material of the enclosures. Being inquisitive, the behavior of bears requires a lot or durability for these enclosures (Miller, 2000). The flooring of enclosures is natural, rock, soil and grass. Electric fencing keeps the bears safe inside rehabilitation center. Safety measures i.e., anti-digging, double entry system and door lock system, are employed to reduce escape risks. Visual barriers prevent the bears to see human caretakers. A fewer number of caretakers are allowed so that cubs are not/less acquainted with human smell. Habitat enrichment is emphasized, such as, water features, climbing structures, trees, logs and stumps are included in enclosures along with denning structures and shelters to avert development of stereotypic behaviors in captivity.

Bear cubs used for reintroduction are raised in a much disciplined system to minimize interactions with caretakers. Experienced rehabilitators raise the cubs with considerable contact till weaning i.e., 5-6 months of age, and afterwards contact is limited. The cubs that arrive around weaning age are raised with restricted and specific interaction of caretakers at start 
of rehabilitation process followed by no direct exposure to the caretakers.

Three (3: 1 male and 2 females) Himalayan black and two (2 female) Himalayan brown bear cubs aging around 2 months old, confiscated/rescued by Provincial Wildlife Department in 2013, were received at the Federal Bear Rescue and Rehabilitation Center, Balkasar (Pakistan) in March 2012. At this age cubs are prone to imprint their caretaker, although bear cubs have forgotten their first home and associate easily. Special arrangements and techniques are employed to not let cubs associate/interact with their caretakers (Hunt et.al. 1988). Cubs arrive with a shattered psyche, having witnessed the killing of their mothers. Cubs are noticed avoiding human interactions several times if caretakers get closer. The best thing with cubs is that they are not single, making it easy for them to adapt to surrounding wild habitat (Beecham and Watkin 2005).

Although active cases of diseases are not reported in wild bears (Binniger et.al. 1980), yet full medical and serological examination is carried out to ensure that cubs do not carry any serious or lethal communicable disease (Beecham and Watkin 2005). During their husbandry, standard hygienic conditions are maintained and exposure to any infection is averted. Though there is no substitute for mother milk, yet high calorie content feed (diluted dried milk with egg yolk) offered to cubs for faster and healthy growth (Jennes et.al., 1972, Huber et.al., 1993, Butterworth 1969, Hulley 1976, Oftedal and Gittleman 1989). Gradually increasing portions of roasted and grinded cereals (barely, grams, wheat, and corn) added to thicken milk at a certain age. Food enrichment (chicken claws, sugar cane, corn cobs, seasonal fruits and vegetables) given at later stages. Quantity of food offered is increased before winters to help them gather fats in body. During winters feed reduced for their hibernation training. Before release cubs observed to avoid their caretaker, which guarantees successful release (Tim 2005. Djuro Huber 2005).

Release Sites: To decide candidate release sites, provincial and federal governments were approached and biologists consulted to short list cub release sites. Wildlife authorities were involved for finalizing the release time and location (Beecham and Watkin 2005). The sites falling within previous bear distribution range of target bear species, having sufficiently large area, good habitat conditions and bear food resources within the prescribed geographical location were considered in selection of release site (Van and Pelton 1997, IUCN, 1998). Due consideration was also given to distance of human settlements from bear release points and the presence of some physical barrier, so that released bears encounter with human inhabitants was limited at least during the first season of release.
Khunjerab National Park $\left(36.26^{\circ} \mathrm{NL}, 75.41^{\circ} \mathrm{E}\right)$ was selected for the release of brown bear. The park is the highest altitude national park in the world, where peaks are $>4000$ masl in elevation. It consists of three valleys, viz., Khunjerab, Ghujerab and Shimshal (Knudesen 1995). The climatic conditions vary with the altitude, yet winters are long and severe with average minimum temperature remaining at $-12^{\circ} \mathrm{C}$ in winter, while summer is cold dry with average maximum temperature of $14{ }^{\circ} \mathrm{C}$. The park has dry alpine scrub with Artemisia spp., Juniperus spp., Rosa webbiana and Polygonum spp. Present on the slopes, whereas Myricaria germanica, Hippophae rhamnoides, Populus nepalensis, Salix spp. and Betula utilis sp.. are found at moist places (Qureshi et.al., 2011). Snow leopard, brown bear, lynx, Tibetan wolf, Tibetan fox, markhor, blue sheep, golden marmot, Himalayan Ibex, Tibetan wild ass, ermine, Alpine weasel, stone martin, large eared Pika are rich food for carnivores (Robert, 1997, Najam, 2012). Brown bear is the key species for the Khunjerab National Park which has not been sighted in the area for the last 10 years (Nawaz, 2007; Abbas et.al., 2015, IUCN, 2018). However, natural brown bear habitats still do exist. Though maintenance of natural biota, including brown bear, is the mandate of the national park, yet local human communities were consulted and taken into confidence for the release/reintroduction of brown bears. The local community ensured their support for the release programme and showed enthusiasm on having their lost species back in the wild.

Kunhar river catchment area (34: $54^{\circ} \mathrm{NL}$, $73.4^{\circ} \mathrm{E} ; 2450-4100$ masl.) was selected for the release of black bears. The site was reported to have some previous black bears population with no recent sighting recorded and was a vacant black bear habitat corridor with surviving populations of bears on two sides. The area has rugged mountains located in the extreme western parts of the Himalayan range beyond which there is the Hindukush range of mountains and the Indus River. It has a moist temperate climate with distinct seasons; longer winters (October-April) and shorter summers (June-September) receiving average annual precipitation of $200 \mathrm{~mm}$ and colder nights with temporary range of $-5{ }^{\circ} \mathrm{C}$ (sometimes touching even -20 ${ }^{\circ} \mathrm{C}$.). Major tree species include Pinus roxburghii, $P$. wallichiana, Acacia modesta, Olea cuspidata, Quercus baloot, Cedrus deodara, Abies pindrow and Picea smithiana. The deciduous population includes Acer sp., Prunus sp., Juglans sp. and, Aesculus sp., along with Betula utilis and Salix krummholz on shady slopes and Juniperus sp. on the sunny slopes with dwarf scrub heaths and meadows above tree line. The southern slopes are covered by Antimesia maritime and Juniperus macropoda (Schickhoff 1993, 1994, Ali and Qaiser 1986). Black bear, red fox, Jackal, honey badger, 
wolf, burrowing vole, field mouse, bats, long tailed marmot and shrews make good food source for carnivores, including bears (Robert 1997, Najam 2012).

Bear Release: The geographical locations and habitat suitability was studied before conducting the release operation following Van and Pelton (1997). Three black (one male and 2 females: age around 22 months, released in April 2015) and 2 brown (both females from different parents: age around 26 months, released in June 2017) bears were microchipped transported from Balkasar Rehabilitation Centre directly to the decided release sites by road in closed containers, ensuring all health parameters, i.e., sufficient supply of fresh air, water, food and cooler temperature. On reaching the release site the animals were allowed to relax for 12 hours to let them get rid of the travel fatigue, and offered food and water. We adopted a hard release technique as per recommendations of IUCN (1998). The release operation was conducted in early part of summer so that the animals get settled before they are exposed to harsh winter conditions. All the bears were released at the same time at one release site at dawn with a clear sky. The shutters of the containers were opened in the early hours of the day, taking necessary safeguards.

Among all bear species, only brown and Asiatic black are known to attack the humans in wild but out of 130 brown bears released in wild in 30 years, there has been no report of damage caused by these bears because of their raising in rehabilitation center (Sergey 2003). Although their aggression is reported but no injury or death of the people has ever been reported.

\section{RESULTS}

Three black bears left the release cage without giving a second thought. They even did not bother to look back though their caretakers were present at the time of the release. The bears climbed up the mountain slope and vanished in the woods. Monitoring of their movement indicated that they remained together for next 23 days in the same area, when one of these got separated from the other two. We could not confirm the sex of the separated individual. We presume it to be a female, leaving the male-female pair remaining associated together. The site selection was based on population depletion point (IUCN 2018).

The two brown females also left the cage and gradually started getting acclimatized to the plan highland pasture of the Khunjerab National Park and both started foraging within a few hours. Further monitoring of their movement suggested that the first two weeks were spent by the bears memorizing the area. It was observed that both the bears roamed in a radius of about $40 \mathrm{~km}$ from the released site and after one year they were observed year deep in the same valley at a distance of some $12 \mathrm{~km}$ from the release site. In September 2018 they were reported $23 \mathrm{~km}$ from Shimshal human settlement when they were searching for food to prepare themselves for their hibernation. During winters they took fats and remained invisible for 3 months and showed themselves in next April when both looked healthy and active.

Present was the first ever successful reintroduction attempt of black and brown bear cubs reared in a rehabilitation center introduced in their vacant natural bear habitats. This suggests that using confiscated bear for reintroduction program, after their rehabilitation, is the best possible alternative offering cubs free life and also enrichment of wild bear populations/gene pools. Such cubs usually end up in cages, zoos or some other inappropriate captivity waiting for their death. Successful release of the black bear gave confidence to authorities and administrative high ups which supported next release of brown bear. Local media also played its role in countrywide dissemination, the news of successful release; highlighting it in the electronic and print media.

\section{DISCUSSION}

Reintroduction is often confused with translocation. Translocation requires wild trained animals from one area released into another, whereas reintroduction attempts establishing a species in some areas falling within historical range of species. Under IUCN guidelines for reintroduction origin of the individuals introduced remains undefined, which could be captive or wild bred cubs (IUCN 1998, Klieiman 1989, Mackinnon and Mackinnon 1991, Sarrazin and Barbauh 1996, Seal 1991, Stuart 1991, Tear et.al. 1993). Compared with reintroduction the success rate of translocated animals is expected to be higher (Beck et.al. 1994, Fischer and Lindenmayer 2000, Wolf et.al. 1996).

Conservation needs coordinated efforts of all segments, recognizing that some groups possess better planning others better practices and some best report writing skills. Such efforts are usually undermined by personal interest of different groups (Riordan 1990) and unbalanced management of governmental institutions resulting in failures despite huge investment, solid plan and best experts (Corson, 2017). Present effort faced criticism with contradictory rumors spread at different times/interest groups about reintroduction of released bears:

1) faced road kill,

2) killed by hunters and skin sold in Gilgit market,

3) attacked villager (at a place $120 \mathrm{~km}$ from the release site), 
4) died of starvation, and

5) reported attacking a village $(250 \mathrm{~km}$ displaced from release site with several physical barriers in between).

Conservation is easier and success oriented if coordinated through science, knowledge and practice (Vasant 2000). Communities ease is prime in conservation however, elements with ultra-desires spread different notions against conservation efforts to detract stakeholder human communities (Vasant 1999, Rangarajan 1996).

Human large carnivore coexistence needs management not eradication of their presence in diverse prey spectrum is important (Ahmad 2013). Reintroduction of bears showed great results. In Arkansas, the population growth and survival rate were high in the empty habitat (Kimberly et.al. 1993). The major criticism is that carnivores raised without parents cannot learn hunting for food which makes their survival difficult, which is not true (Fabregas et.al 2015). Reintroduction of bears from captivity has been suggested by IUCN (2013). Pre-release conditioning can guarantee successful survival of released animals (Kleiman et.al 1986, Philips 1990, Soderquist and Serena 1994, Stanley Price 1989, Vargas and Anderson 1999). Hundreds of successfully researched bears (Kotler and Van Dijk 2005) were introduced during the last 30 years after raising them up to self-sufficient size/age in North America (Clark et.al. 1980, Alt and Beecham, 1984). Reintroduced bears dispersed 34-400 $\mathrm{Km}$ from their release site in two years (Binks 2008). In the last 15 years, brown bears in Russia and South Korea, sun bears in Indonesia, and Andean bear in Ecuador, were successfully reintroduced (John 2005, Gabriella 2006, Armando 2005, Kolter 2005). IUCN reported that four out of six species of bears are actively reintroduced globally (IUCN 2002).

\section{REFERENCES}

Abbas, F., Z.I. Bhatti, J. Haider, and A. Mian (2015). Bears in Pakistan: Distribution, Population Biology and Human Conflicts. J. Biores. Manage. 2(2).

Ahmad, A., S. Khan, and H. Ahmad (2013). Status and conservation of Himalayan brown bear (Ursus arctos isabellinus) in Bashqar Gol district Chitral, Pakistan. Tiger paper. 40(4): 21-25.

Ali, S.I., and M. Qaiser (1986). A Phyto-Geographical analysis of the Phenerogames of Pakistan and Kashmir. Proc. Royal Soc. Edinb. 89: 89-101.

Ali, U., R.A. Minhas, M.S. Awan, K.B. Ahmed, Q.Z. Qamar, and N.I. Dar (2016). Human-Grey Wolf (Canis lupus Linnaeus, 1758) Conflict in Shounther Valley, District Neelum, Azad Jammu and Kashmir. Pakistan J. Zool. 48(3): 861-868.
Alt, G.L., and J.J. Beecham (1984). Reintroduction of orphaned black bear cubs into the wild. Wildl. Soc. Bull. 12:169-174.

Castellanos, A. Espiritu del Bosque, Ecuador. personal comm. (August, 2005).

Ballenberghe, V.V. (2006). Predator control, politics and wildlife conservation in Alaska, Alces, 42: $1-11$.

Beck, B.B., L.G. Rapaport, M.R.S. Price, and A.C. Wilson (1994). Reintroduction of captive-born animals. Creative Conservation: Interactive Management of Wild and Captive Animals. Olney, P.J.S., Mace, G.M., Feistner, A.T.C. (Eds.). Chapman and Hall; (London). 264-386 p.

Beecham, J.J., and V. Watkins (2005). Rehabilitation and release of orphaned bear cubs. Poster, 16th International Conference on Bear Research and Management, Riva del Garda, Italy.

Binks, M.J. (2008). Post-release behaviour and survival of shelter reared, juvenile black bears in central Ontario. M.S. Thesis. Laurentian University, Sudbury. 92 p.

Binninger, C.E., J.J. Beecham., L.A. Thomas, and L.D. Winward (1980). A serologic survey for selected infectious diseases of black bears in Idaho. J. Wildl. Dis. 16(3): 423-430.

Butterworth, B.B. (1969). Postnatal growth and development of Ursus americanus. J. Mamm. 50: 615-616.

Corson, C. (2017). A history of conservation politics in Madagascar. Madag. conserv dev. 12(1). 1-12

Clark, S.H., J. O'Pezio, and C. Hackford (1980). Fostering black bear cubs in the wild. Intern. Conf. Bear Res. and Manage. 4: 163-166.

Criswell, A.R., and G.J. Galbreath (2005). Behavioral persistence in captive bears: a critique. Ursus. 16(2): 268-273.

Dar, N.I., R.A. Minhas, Q. Zaman, and M. Linkie (2009). Predicting the patterns, perceptions and causes of human-carnivore conflict in and around Machiara National Park. Pakistan Biol. Conserve. 142(10): 2076-2082.

Huber, D. Univ. of Zagreb, Croatia, personal comm. (December, 2005).

Erickson, A.W. (1959). The age of self-sufficiency in the black bear. J. Wildl. Manage. 23: 401-405.

Fàbregas, M.C., G.T. Fosgate, and G.M. Koehler (2015). Hunting performance of captive-born South China tigers (Panthera tigris amoyensis) on free-ranging prey and implications for their reintroduction. Biol. Conserv. 192: 57-64 IUCN (2013).

Fischer, J., and D. Lindenmayer (2000). An assessment of the published results of animal relocations. Biol. Conserv. 96: 1-11. 
Fredrickson G., Univ. of Amsterdam, Netherlands, personal comm. (January 2006).

Goodrich, J. WCS, Russia, personal comm., (February, 2005).

Gulez, S. (1992). A method of evaluating areas for national park status. Environ. Manag. 16(6): 811-818.

Huber, D., I. Kulier, A. Poljak, and B. Devjic-Kuhar (1993). Food intake and mass gain of handreared brown bear cubs. Zoo. Biol. 12: 525-533.

Hulley, J.T. (1976). Hand-rearing American black bear cubs Ursus americanus at Toronto Zoo. International Zoo Yearbook. 16: 202-205.

Hunt, C.L., F. Hammond, and C. Peterson (1988). Behavioral responses of Yellowstone ecosystem grizzly bears to aversive conditioning techniques. Wyoming Game and Fish Dep., Progress Report, Cody, Wyoming. 68 p.

IUCN (1998). Guidelines for Re-Introductions. IUCN/SSC Re-Introduction Specialist Group, IUCN, Gland, Switzerland and Cambridge, UK.

IUCN (2018). The IUCN Red List of Threatened Species. Version 5.2. http://www.iucnredlist.org. Downloaded on 8$12-2018$

IUCN (2018). The IUCN red list of threatened species version 3-5-2017. http://www.iucnredlist.org, downloaded on (12-12-2018)

IUCN (2002). IUCN Guidelines for the placement of confiscated animals. Prepared by 58 .

IUCN/SSC Re-introduction Specialist Group. IUCN, Gland, Switzerland and ERWDA, Abu Dhabi, UAE. 24 p.

IUCN/SSC, (2013). Guidelines for Reintroductions and Other Conservation Translocations. Version 1.0. IUCN Species Survival Commission, VIIII, Gland.

Jenness, R., A.W. Erickson, and J.J. Craighead (1972). Some comparative aspects of milk from four species of bears. J. Mamm. 53: 34-47.

Khorozyan, I., A. Ghoddous, M. Soof, and M. Waltert (2015). Big cats kill more livestock when wild prey reaches a minimum threshold. Biol. Conserv. 192: 268-275.

Kleiman, D.G. (1989). Reintroduction of captive mammals for conservation. Bioscience. 152$161 \mathrm{p}$.

Knudsen, A.J. (1995). State intervention and community protest: Nature conservation in Hunza, North Pakistan. Ole Bruun and Arne Kalland, Eds. Asian Perceptions of Nature: A Critical Approach. Curzon Press. Richmond. 103-125 p.

Kolter, L., and J.V. Dijk (2005). Rehabilitation and release of bears. Cologne: Zoologischer Garten
Köln. Leonardo Bereczky, Vier Pfoten, Romania, personal comm.

MacKinnon, K., and J. MacKinnon (1991). Habitat protection and reintroduction programmes. In: Gipps, J.H.W. (Ed.), Beyond Captive Breeding: Re-introducing Endangered Mammals to the Wild. Clarendon Press, Oxford. 173-196 p.

Manley, T. MDFWP, USA, personal comm., (December 2005).

Meriggi, A., and S. Lovari (1996). A review of wolf predation in southern Europe: does the wolf prefer wild prey to livestock. J. Appl. Ecol. 33: 1561-1571.

Miller, E.A. (2000). Minimum standards for Wildlife Rehabilitation. 3rd ed. National Wildlife Rehabilitation Association. St. Cloud, MN. 77 p.

Khan, N.U.H. (2012). Coastal Lagoons to Alpine Lakes: A Guidebook to Pakistan's Significant Wetlands book WWWF Pakistan.

Nawaz, M.A. (2007). Status of the brown bear in Pakistan. Ursus. 18: 89-100.

Oftedal, O.T., and J.L. Gittleman (1989). Patterns of energy output during reproduction in Carnivore behavior, ecology and evolution. J.L. Gittleman, eds. Chapman and Hall, London. 355-378 p.

Palomero, G., J.C. Blanco, P. Garcia, and G. Palomero (1997). Ecology and behavior of three wild orphaned brown bear cubs in Spain. Int. Conf. Bear Res. and Manage. 9(2): 85-90.

Phillips, M.K. (1990). Measures of the value and success of a reintroduction project: red wolf reintroduction project in alligator river national wildlife refuge. Endanger. Species Updat. 8: 24-26.

Price, S.M.R. (1989). Animal Re-Introductions: The Arabian Oryx in Oman. Cambridge University Press. Cambridge.

Qureshi, R., W.A. Khan, G.R. Bhatti, B. Khan, S. Iqbal, M.S. Ahmad, and M. Abid (2011). First report on the biodiversity of Khunjerab National Park, Pakistan. Pakistan J. Bot. 43: 849-861.

Rangarajan, M. (1996). The politics of ecology: The debate on wildlife and people in India, (19701995). Econ. Political Wkly. 31(35-36-37): 2391-2406.

Roberts, T.J. (1997). The Mammals of Pakistan (revised ed.). Oxford University Press; Karachi (Pakistan).

Saberwal, V.K. (2000). Conservation as Politics: Wildlife Conservation and Resource Management in India. J. Int. Wildl. Law Policy. 3(2): 166.

Sarrazin, F., and R. Barbault (1996). Reintroduction: challenges and lessons for basic ecology. 
Trends in Ecology and Evolution. 11(11): 474478.

Schickhoff, U. (1993). Das Kaghan-Tal im Westhimalaya (Pakistan). Studien zur landschaftsökologischen Differenzierung und zum Landschaftswandel mit vegetationskundlichem Ansatz. Bonner Geographische Abhandlungen 87. - (1994): Die Verbreitung der Vegetation im Kaghan-Tal (Westhimalaya, Pakistan) und ihre kartographische Darstellung im Maßstab 1: 150 000. Erdkunde, 48:92-110. (1995): Verbreitung, Nutzung und Zerstörung der Höhenwälder im Karakorum und in angrenzenden Hochgebirgsräumen Nordpakistans. Petermanns Geographische Mitteilungen, 139: 67-85.

Schickhoff, U. (1994). Die Verbreitung Der Vegetation Im Kaghan-Tal (Westhimalaya, Pakistan) Und Ihre Kartographische Darstellung Im Massstab 1: 150000 (The Distribution of Vegetation in the Kaghan Valley (Western Himalaya, Pakistan) and Its Cartographic Representation at a Scale of 1: 150.000). Erdkunde. 48(2):292110. http://www.jstor.org/stable/25646553.

Seal, U.S. (1991). Life after extinction. Gipps, J.H.W., (Ed.), Beyond Captive Breeding: Reintroducing Endangered Mammals to the Wild, Symp. Zool. Soc. Lond. Clarendon Press. Oxford. London. 62: 39-53.

Sergey P., IFAW, Russia, personal comm., (April 2003).

Shehzad W., A. Nawaz, F. Pompanon, E. Coissac, T. Riaz, S.A. Shah, and P. Taberlet (2014). Forest without prey; livestock sustain a leopard Panthera pardus population in Pakistan. Oryx. 49: 248-253.

Sheikh, K.M., and S. Molur (2004). (Eds.) Status and Red List of Pakistan's Mammals. Based on the Conservation Assessment and Management Plan. IUCN, Pakistan. 312 p.

Smith, K.G., J.D. Clark, D. Scott, and Shull (1993). The reintroduction of Black bears in Arkansas.
Bears: majestic creatures of the wild. Rodale Press, New York. 222 p

Soderquist, T., and M. Serena (1994). An experimental reintroduction programme for brush tailed phascogales (Phascogale tapoatafa): the interface between captivity and the wild. Olney, P.J., G. Mace, A. Feistner (Eds.), Creative Conservation: interactive management of wild and captive species. Springer. 431-438 p.

Stuart, S.N. (1991). Re-introductions: to what extent are they needed? Gipps, J.H.W. (Ed.) Beyond Captive Breeding: Reintroducing Endangered Mammals to the Wild, Symp. Zool. Soc. Lond. Clarendon Press. Oxford. London. 62: 27-37 p.

Riordan, T.O. (1990). The ever-changing politics of nature conservation in the United Kingdom Environment and Planning. 22: 143-147.

Tear, T.H., J.M. Scott, P.H. Hayward, and B. Griffith. (1993). Status and prospects for success of the endangered species act: a look at recovery plans. Sci. 262: 976-977.

Van Manen, F.T., and M.R. Pelton (1997). Procedures to enhance the success of a black bear reintroduction program. Int. Conf. Bear Res. and Manage. 9(2): 67-78.

Vargas, A., and S.H. Anderson (1999). Effects of experience and cage enrichment on predatory skills of black-footed ferrets (Mustela nigripes). J. Mammal. 80: 263-269.

Saberwal, V. (1999). Pastoral Politics: Shepherds, Bureaucrats and Conservation in the Western Himalaya. Oxford University Press. Delhi.

Vickery, S., and G. Mason (2003). Behavioral persistence in captive bears: implications for reintroduction. Ursus. 14: 35-43.

Wolf, C.M., B. Griffith, C. Reed, and S. Temple (1996). Avian and mammalian translocations: update and reanalysis of 1987 survey data. Conserv. Biol. 10 (4): 1142-1154.

Worster, D. (1985). Nature's economy: A history of ecological ideas. 2nd Ed. Cambridge University Press. 34 p. 


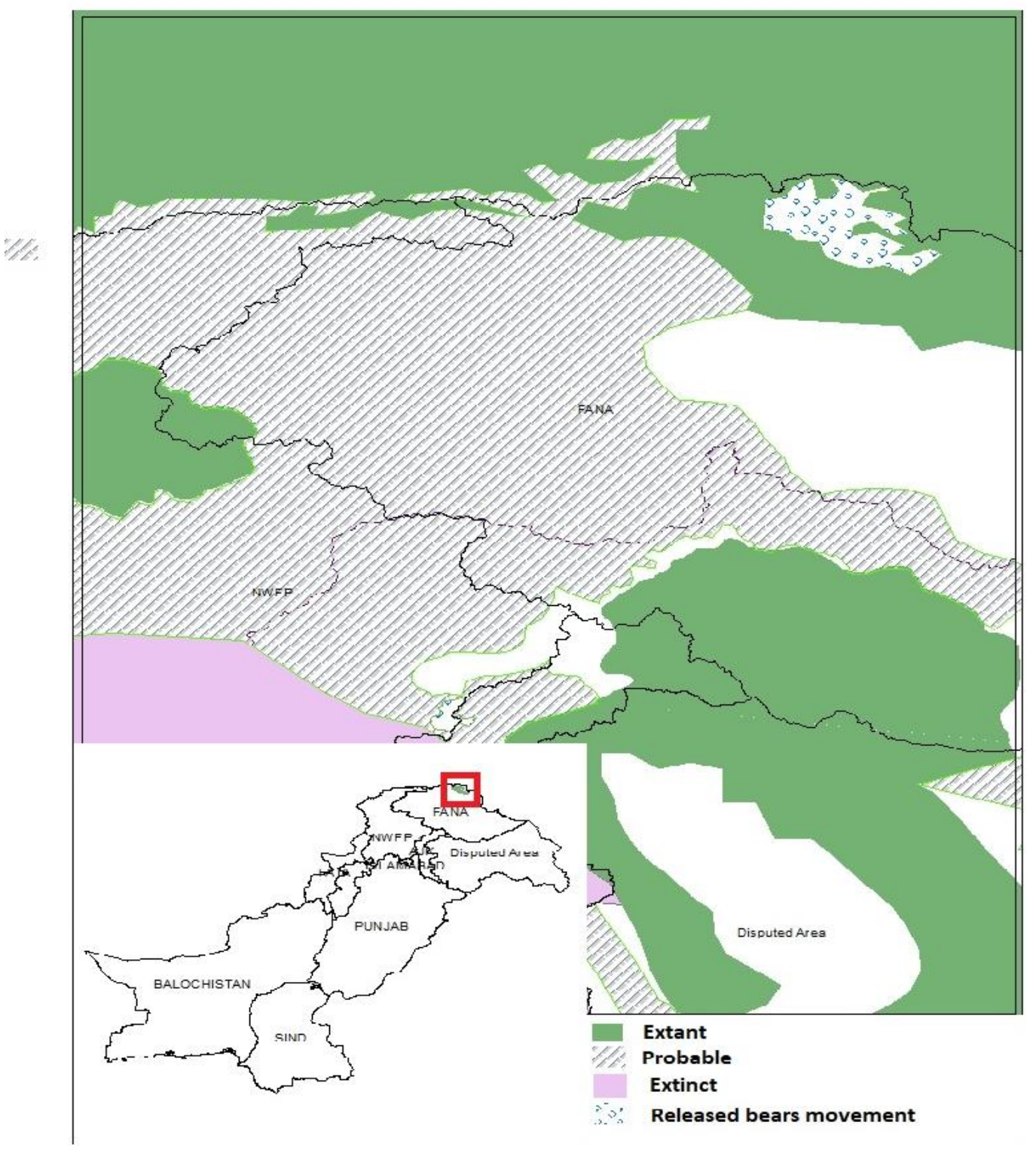

Brown Bear release 


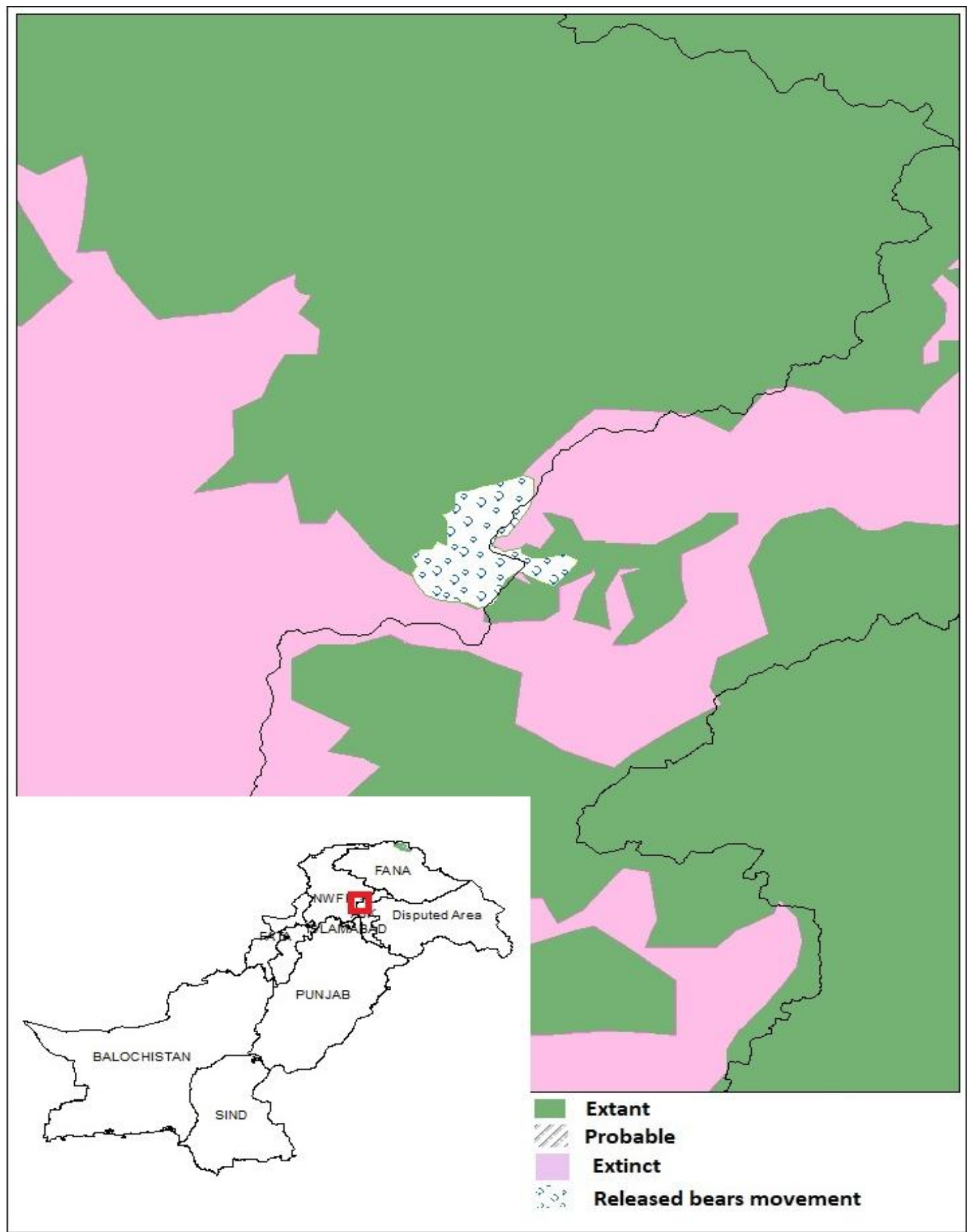

Black bear release 